\title{
Prevalence and correlates of preterm labor among young parturient women attending public hospitals in Brazil
}

\author{
Angélica E. Miranda, ${ }^{1}$ Valdir M. Pinto, ${ }^{1}$ Célia L. Szwarcwald, ${ }^{2}$ \\ and Elizabeth T. Golub ${ }^{3}$
}

Suggested citation Miranda AE, Pinto VM, Szwarcwald CL, Golub ET. Prevalence and correlates of preterm labor among young parturient women attending public hospitals in Brazil. Rev Panam Salud Publica. 2012;32(5):330-4.

ABSTRACT Objective. To determine the prevalence of and risk factors for preterm labor $(<37$ weeks of gestation) among young pregnant women in Brazil.

Methods. A national cross-sectional study was conducted among parturient women aged 15-24 years attending Brazilian public maternities in 2009. Questionnaires were administered by interviewers during parturient admission to the maternity clinic (or soon after delivery, if survey participants were in too much pain to respond during labor). The questionnaires collected demographic, behavioral, and clinical data.

Results. A total of 2071 (86.3\%) of the 2400 parturient women invited to participate were included in the study. Mean age was 20.2 years (standard deviation [SD]: 2.7) and mean years of formal education was 8 (SD: 2.4). Preterm labor occurred in 450 women (21.7\%). The highest proportion of premature labor $(36.1 \%)$ was found in the North region and the lowest proportion (6.9\%) was found in the South region. In the final multivariate logistic regression model, living in the North region (odds ratio [OR]: 1.43, 95\% confidence interval [CI]: 1.281.59); having monthly income less than twice the Brazilian minimum wage (OR: 1.27, 95\% CI: 1.01-1.60); having suffered domestic violence (OR: 2.27, 95\% CI: 1.23-4.18); and having had inadequate prenatal care (OR:3.17,95\% CI: 2.54-3.97) remained significant correlates of preterm labor in this population.

Conclusions. Results show a high prevalence of preterm labor among young women in Brazil. Preterm labor has multifactorial etiologies. More public health resources must be directed toward accelerating understanding of this complex process.

Key words Obstetric labor, premature; pregnancy in adolescence; prenatal care; Brazil.

Preterm labor, defined as childbirth occurring at less than 37 completed weeks of gestation, is a major determinant of

1 Núcleo de Doenças Infecciosas, Universidade Federal do Espírito Santo, Vitória, ES, Brazil. Send correspondence to Angélica Espinosa Miranda, espinosa@ndi.ufes.br

2 Instituto de Comunicação e Informação Científica e Tecnológica em Saúde, Fiocruz, Rio de Janeiro, RJ, Brazil.

3 Department of Epidemiology, Johns Hopkins Bloomberg School of Public Health, Baltimore, MD, United States of America. neonatal mortality and morbidity and has long-term adverse consequences for health $(1,2)$. Despite major preventive efforts, the incidence of preterm labor has remained constant at about 5\%-10\% of live births in most countries $(3,4)$.

In $75 \%$ of preterm labor cases, no obvious causes have been established, but some risk factors have been identified $(4,5)$. Nonobstetric risk factors include poor socioeconomic status (6); maternal malnutrition and illiteracy (7); maternal age of $<20$ or $>35$ years $(8,9)$; cigarette smoking $(10,11)$; and trauma (12). Obstetric risk factors include cervical incompetence; multiple gestations; short birth intervals; abortion; premature rupture of membrane; and previous preterm labor $(1,5,13)$. Other medical conditions (diabetes mellitus, urinary and genital tract infections) have also been associated with preterm labor $(5,9,10)$. 
Official data from the Brazilian Ministry of Health showed a prevalence of preterm birth in Brazil of $6.5 \%$ in 2009 (14). A systematic review conducted in Brazil in 2008 found a prevalence of preterm labor ranging from $3.4 \%$ to $15.0 \%$ in the South and Southeast regions between 1978 and 2004, and from 3.8\% to $10.2 \%$ in the Northeast region between 1984 and 1998. No data were found from the North or Central-West regions (15).

Adolescent girls who give birth each year have a much higher risk of delivery complications compared to older women $(8,9)$. Moreover, babies born to adolescents face higher risk of complications compared to babies born to older women $(5,8)$. This study sought to determine the prevalence of and risk factors for preterm labor among young pregnant women in Brazil. The results will be used in the elaboration of public health policies to identify indicators for monitoring preterm labor prevention strategies.

\section{MATERIALS AND METHODS}

This cross-sectional study was conducted among parturient women aged 15-24 years who were attending Brazilian public maternity units in 2009. Parturient women attending selected maternity units in Brazil's five geographic macro-regions (North, Northeast, Central-West, South, and Southeast) from March to November 2009 were invited to take part in the study.

\section{Data collection}

Questionnaires were administered by interviewers during parturient admission to the maternity clinic (or soon after delivery, if participants were in too much pain to respond during labor). The questionnaires collected sociodemographic data (age, race, level of formal education, marital status, and family income); clinical data (gestational age and number of pregnancies, childbirths, miscarriages/abortions, and prenatal examinations performed); sexual behavior (age at first sexual intercourse, prior history of sexually transmitted infections [STIs], number of sex partners in past year and lifetime, and bisexual practices); and STI/HIV risk behavior (drug use, sex in exchange for money/ goods, sex partners' history of blood transfusions, and history of imprisonment). Participants were also asked if they had any gynecological problems during pregnancy (pelvic pain, bleeding, vaginal discharge, urinary infections). Gestation age was determined by age of last monthly period and confirmed by first-trimester obstetric ultrasound. Family income was measured in number of Brazilian minimum wages (BMWs) (one BMW in 2009 was approximately US\$ 250). To comply with Brazilian Ministry of Health protocol, "adequate prenatal care" was defined as "at least six prenatal health care visits."

\section{Sampling}

In the first stage of sampling, 24 public health system maternity units were randomly chosen. Selection of maternity units was stratified by Brazilian geographic macro-region with proportional allocation to number of childbirths in the year before the study (2008). In the second stage, 100 women were selected from each participating unit at the time of their admission for childbirth.

\section{Statistical analysis}

The study outcome was preterm labor ( $<37$ weeks of gestation). A preliminary analysis was performed, using exploratory techniques on the data, to check the distribution patterns and trends of the principal variables. Chi-square and Fisher's tests were used to test qualitative associations, and Student's t-tests and variance analysis were used for testing differences between mean values. Logistic regression analysis was conducted to estimate associations of relevant covariates with preterm labor. Univariate and multivariate odds ratios (ORs) (adjusting for potential confounders) and 95\% confidence intervals (CIs) were reported. Variables that were significant at $P<0.15$ in bivariate analysis, and known confounders (e.g., age and education), were considered in the multivariate analysis using a stepwise multiple logistic regression model. Data were analyzed using SPSS version 17.0 for Windows (Chicago, IL, USA).

\section{Ethical aspects}

This project was submitted to and approved by the human research ethics committee of the Health Sciences Center of the Federal University of Espírito Santo (approval no. 112/07) as well as the committee of each maternity unit participating in the study. All of the selected mothers-tobe were invited to take part voluntarily in the study, and those who accepted signed a written term of consent.

\section{RESULTS}

A total of 2071 (86.3\%) of the 2400 parturient women invited to participate were included in the study $(13.7 \%$ declined to participate). No specific information was gathered about nonrespondents. Mean age was 20.2 years (SD: 2.7) and mean years of formal education was 8 (SD: 2.4). Preterm labor occurred in 450 women $(21.7 \%)$. The highest proportion of premature labor $(36.1 \%)$ was found in the North region and the lowest $(6.9 \%)$ was found in the South region (Table 1). Table 2 describes demographic characteristics of the study participants. Domestic violence against women $(4.7 \%$ versus $1.9 \%, P=0.002)$ and inadequate prenatal care $(63.8 \%$ versus $33.5 \%, P=$ 0.013 ) were more frequent among premature labor cases versus at-term labor cases in bivariate analysis (Table 3 ).

A total of 1974 women $(95.3 \%)$ attended prenatal care. Of those women, 1241 (about 63\%) had followed the protocol of the Ministry of Health for prenatal care (having six or more prenatal care visits). Onset of sexual activity ranged from 9 to 24 years of age, with a mean of

TABLE 1. Proportion of women undergoing preterm labor among parturient women attending public maternity units ( $n=2$ 071), by geographic area, Brazil, 2009

\begin{tabular}{lccc}
\hline & \multicolumn{2}{c}{ Women undergoing preterm labor } & \\
\cline { 2 - 3 } Geographic area & No. $/ n$ & $\%$ & $95 \% \mathrm{Cl}^{\mathrm{a}}$ \\
\hline North region & $97 / 269$ & 36.1 & $30.4-41.8$ \\
Northeast region & $191 / 696$ & 27.4 & $24.1-30.7$ \\
Southeast region & $113 / 714$ & 15.8 & $13.1-18.5$ \\
South region & $16 / 233$ & 6.9 & $3.6-10.2$ \\
Central-West region & $33 / 159$ & 20.8 & $14.5-27.1$ \\
Brazil & $450 / 2071$ & 21.7 & $19.7-23.3$ \\
\hline
\end{tabular}

a Cl: confidence interval. 
TABLE 2. Socio-demographic characteristics of parturient women attending public maternity units ( $n=2$ 071), by type of labor, Brazil, 2009

\begin{tabular}{|c|c|c|c|}
\hline & Preterm labor & At-term labor & \\
\hline Characteristic & No. $(\%)$ & No. (\%) & $\mathrm{OR}^{\mathrm{a}}\left(95 \% \mathrm{Cl}^{\mathrm{b}}\right)$ \\
\hline \multicolumn{4}{|l|}{ Age (years) } \\
\hline $15-19$ & $184(40.9)$ & $983(60.6)$ & $1.1(0.9-1.3)$ \\
\hline $20-24^{c}$ & $266(59.1)$ & $638(39.4)$ & 1 \\
\hline \multicolumn{4}{|l|}{ Formal education (years) } \\
\hline$\leq 8$ & $275(61.1)$ & $949(58.5)$ & $1.1(0.9-1.4)$ \\
\hline$>8^{c}$ & $175(38.9)$ & $672(41.5)$ & 1 \\
\hline \multicolumn{4}{|l|}{ Marital status } \\
\hline Does not live with partner & $122(27.1)$ & $453(27.9)$ & $1.0(0.8-1.2)$ \\
\hline Married or living together ${ }^{c}$ & $328(72.9)$ & $1168(72.1)$ & 1 \\
\hline \multicolumn{4}{|l|}{ Monthly income } \\
\hline$<2 \mathrm{BMW}^{\mathrm{d}}$ & $262(58.2)$ & 937 (57.8) & $1.0(0.8-1.3)$ \\
\hline$\geq 2 \mathrm{BMW}^{\mathrm{C}}$ & $188(41.8)$ & $684(42.2)$ & 1 \\
\hline \multicolumn{4}{|l|}{ Geographic region } \\
\hline North & $97(21.6)$ & $172(10.6)$ & $2.1(1.4-3.4)$ \\
\hline Northeast & $191(42.4)$ & $505(31.1)$ & $1.4(0.9-2.2)$ \\
\hline Southeast & $113(25.1)$ & $601(37.1)$ & $0.7(0.5-1.1)$ \\
\hline South & $16(3.6)$ & $217(13.4)$ & $0.3(0.2-0.5)$ \\
\hline Central-West ${ }^{c}$ & $33(7.3)$ & $126(7.8)$ & 1 \\
\hline
\end{tabular}

TABLE 3. Behavioral and clinical characteristics of parturient women attending public maternity units ( $n=2$ 071) and their association with preterm labor, Brazil, 2009

\begin{tabular}{|c|c|c|c|}
\hline & Preterm labor & At-term labor & \\
\hline Characteristic & No. (\%) & No. (\%) & $\mathrm{OR}^{\mathrm{a}}\left(95 \% \mathrm{Cl}^{\mathrm{b}}\right)$ \\
\hline \multicolumn{4}{|c|}{ Age at first sexual intercourse } \\
\hline$<15$ years & $164(36.4)$ & $515(31.8)$ & $1.4(1.0-1.5)$ \\
\hline$\geq 15$ years $^{c}$ & $286(63.6)$ & $1106(68.2)$ & 1 \\
\hline \multicolumn{4}{|l|}{ Domestic violence } \\
\hline Yes & $21(4.7)$ & $31(1.9)$ & $2.5(1.4-4.4)$ \\
\hline $\mathrm{No}^{\mathrm{C}}$ & 429 (95.3) & $1590(98.1)$ & 1 \\
\hline \multicolumn{4}{|l|}{$\begin{array}{l}\text { Tobacco use during } \\
\text { pregnancy }\end{array}$} \\
\hline Yes & $23(5.1)$ & $80(4.9)$ & $1.0(0.6-1.6)$ \\
\hline Noc & 427 (94.9) & $1541(95.1)$ & 1 \\
\hline \multicolumn{4}{|l|}{ Illicit drug use } \\
\hline Yes & $30(6.7)$ & $96(5.9)$ & $1.1(0.7-1.7)$ \\
\hline $\mathrm{No}^{\mathrm{C}}$ & 420 (93.3) & $1525(94.1)$ & 1 \\
\hline \multicolumn{4}{|l|}{ Adequate prenatal care ${ }^{d}$} \\
\hline No & $287(63.8)$ & $543(33.5)$ & $3.5(2.8-4.3)$ \\
\hline Yes $^{c}$ & $163(36.2)$ & $1078(66.5)$ & 1 \\
\hline \multicolumn{4}{|l|}{ Previous abortion } \\
\hline Yes & $7(1.6)$ & $30(1.9)$ & $0.8(0.3-1.9)$ \\
\hline $\mathrm{No}^{\mathrm{C}}$ & $443(98.4)$ & $1591(98.1)$ & 1 \\
\hline \multicolumn{4}{|c|}{ Abnormal vaginal discharge } \\
\hline Yes & $70(15.6)$ & 254 (15.7) & $1.0(0.7-1.3)$ \\
\hline $\mathrm{No}^{\mathrm{C}}$ & 380 (84.4) & 1367 (84.3) & 1 \\
\hline \multicolumn{4}{|l|}{$\begin{array}{l}\text { Urinary infection during } \\
\text { pregnancy }\end{array}$} \\
\hline Yes & $17(3.8)$ & $44(2.7)$ & $1.4(0.8-2.5)$ \\
\hline $\mathrm{No}^{\mathrm{C}}$ & 433 (96.2) & 1577 (97.3) & 1 \\
\hline \multicolumn{4}{|l|}{ Chlamydia test } \\
\hline Positive & $54(12.0)$ & $148(9.1)$ & $1.4(1.0-1.9)$ \\
\hline Negative $^{c}$ & $396(88.0)$ & $1473(90.9)$ & 1 \\
\hline
\end{tabular}

15.6 years (SD: 2.7 ), and $0.7 \%$ and $0.9 \%$ of the study participants tested positive for HIV and syphilis respectively during labor. These proportions did not differ significantly between preterm and atterm groups (data not shown).

In the final multivariate logistic regression model, living in the North region
(OR: 1.43 , 95\% CI: 1.28-1.59); having a monthly income less than twice the Brazilian minimum wage (OR: 1.27, 95\% CI: 1.01-1.60); having suffered domestic violence (OR: 2.27, 95\% CI: 1.23-4.18); and having had inadequate prenatal care (OR: 3.17, 95\% CI: 2.54-3.97) remained significant correlates of preterm labor in this population (Table 4 ).

\section{DISCUSSION}

A prevalence of $21.7 \%$ was found for preterm labor among young women attending public hospitals in Brazil. This rate was higher than the official rate reported by the Ministry of Health for this age group in 2009 (6.5\%) (14). However, the official number may be skewed. A review of studies published in periodicals, theses, and dissertations from 1950 to 2005 and listed in the MEDLINE and LILACS (Latin American and Caribbean Literature on the Health Sciences) databases indicated prevalence of preterm delivery ranged from $3.4 \%$ to $15.0 \%$ in the South and Southeast regions between 1978 and 2004 and from 3.8\% to $10.2 \%$ in the Northeast region between 1984 and 1998, with a rising trend from the 1990s onward in all regions (15). No data specific to preterm delivery among young women (15-24 years old) were found. Skewing of the official estimate could have resulted from inaccurate estimation of gestational age and/or poor record management caused by information system quality control issues. On the other hand, the higher prevalence rate reported by the Ministry of Health may be accurate, as prenatal care is inadequate, delayed, and sometimes nonexistent in some remote areas of Brazil (16).

The results of the current study show a positive association between preterm labor and low monthly income, domestic violence, and inadequate prenatal care. These risk factors, which are all associated with low socioeconomic status, were described in previous studies carried out in Brazil and other countries $(6,9,12,17,18)$. Given the link between preterm labor and socioeconomic status, systematic evaluation of socioeconomic risk factors is recommended in developing prevention strategies. Low monthly income in Brazil represents lower access to health care and goods. The effects of domestic violence, along with sexual and racial violence, on the physical and mental health of women have been re- 
TABLE 4. Multivariate analysis of characteristics associated with preterm labor among parturient women attending public maternity units ( $n=2$ 071), Brazil, 2009

\begin{tabular}{|c|c|c|c|}
\hline Characteristic & Adjusted OR ${ }^{a}$ & $95 \% \mathrm{Cl}^{\mathrm{b}}$ & $P$-value ${ }^{\mathrm{c}}$ \\
\hline Lives in North region (vs. other regions ${ }^{d}$ ) & 1.43 & $1.28-1.59$ & 0.001 \\
\hline Age $15-19$ years (vs. 20-24 years) & 1.06 & $0.84-1.33$ & 0.617 \\
\hline Education $\leq 8$ years (vs. $>8$ years) & 1.05 & $0.83-1.32$ & 0.693 \\
\hline 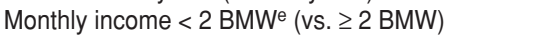 & 1.27 & $1.01-1.60$ & 0.044 \\
\hline Domestic violence (yes vs. no) & 2.27 & $1.23-4.18$ & 0.009 \\
\hline Tobacco use during pregnancy (yes vs. no) & 1.04 & $0.63-1.75$ & 0.864 \\
\hline Age $<15$ years at first intercourse (vs. $\geq 15$ years) & 1.07 & $0.86-1.73$ & 0.580 \\
\hline Prenatal care: $<6$ visits (vs. $\geq 6$ visits) & 3.17 & $2.54-3.97$ & 0.001 \\
\hline Urinary infection during pregnancy (yes vs. no) & 1.36 & $0.73-2.50$ & 0.331 \\
\hline Chlamydia infection (yes vs. no) & 1.22 & $0.86-1.73$ & 0.270 \\
\hline
\end{tabular}

a OR: odds ratio.

${ }^{b} \mathrm{Cl}$ : confidence interval.

c Hosmer-Lemeshow test chi-square $=1.826 ; P=0.837$.

d Northeast, Central-West, South, and Southeast.

e BMW: Brazilian minimum wage (1BMW = US\$ 250 in 2009).

ported elsewhere (19-21). Although domestic violence was not the focus of the current study, it is important to document its prevalence and investigate its association with other health problems in young women.

No association was found in the current study between preterm delivery and other risk factors described in previous studies, such as cigarette smoking, urinary and genital infection, and previous abortion $(5,7,10,11)$. The rate of smoking found in this study was lower than that reported in previous Brazilian studies $(22,23)$. This may be due to the fact that the current sample comprised younger adults. Previous Brazilian studies have shown a smoking prevalence for that population of only about 6\% (24, $25)$, similar to the findings of the current study.

The current results also indicated an association between preterm labor and living in the North region of Brazil. This may be due to regional disparities in socioeconomic conditions and access to health care. Difficulties regarding access to health care are mainly centered in the Amazonas area $(16,26)$. Although access to most maternal and child health interventions increased sharply to almost universal coverage in the last few decades, and regional and socioeconomic inequalities in access to such interventions were notably reduced, substantial challenges remain, including over-medicalization of childbirth, maternal deaths

1. Lumley J. Defining the problem: the epidemiology of preterm birth. BJOG. 2003;110 Suppl 20:3-7.

2. Lawn JE, Wilczynska-Ketende $\mathrm{K}$, Cousens SN. Estimating the causes of 4 million neo- caused by illegal abortions, and a high frequency of preterm deliveries (26).

\section{Limitations}

This study had several limitations. First, cross-sectional studies are not ideal for determining risk factors. Nevertheless, the data obtained by this study on preterm labor prevalence and risk factors in young women at the most fertile age are extremely important for demonstrating the susceptibility of this population to the complications that arise during the pregnancy-childbirth cycle. Second, the low prevalence of some of the risk factors in the study sample was not taken into account when calculating the sample size, so the number of women studied was not adequate for determining the statistical association between some independent variables and preterm labor. Third, there was a strong potential for bias in the questionnaire responses due to the general tendency for survey participants to give socially acceptable responses. Finally, because the study was limited to public hospitals, no inferences about preterm deliveries at private hospitals can be derived from the results.

\section{Conclusions}

The results of this study show a high prevalence of preterm labor in young women in Brazil. Complications in preg-

\section{REFERENCES}

natal deaths in the year 2000. Int J Epidemiol. 2006;35(3):706-18.

3. Wen SW, Smith G, Yang Q, Walker N. The epidemiology of preterm birth and neona- nancy are more frequent among younger women, so evaluation of risk factors specific to that population is crucial when planning prevention and assistance strategies. In addition, more resources must be directed toward accelerating understanding of preterm labor's multifactorial etiologies and identifying upstream and cost-effective ways to reduce the prevalence of this pregnancy outcome (27). Preterm labor is an important concern for public health because of the birth complications that arise from immature organ systems that are not yet prepared to support life in the extrauterine environment. The response of the infant's organ systems to the demands of that environment and the life support that is subsequently provided have an important impact on the infant's shortand long-term health and neurodevelopmental outcomes (28). Increasing availability of and access to early and adequate prenatal care could help prevent pregnancy complications and provide peace of mind to women worried about the outcome of their pregnancy. Establishing a surveillance system to monitor preterm delivery, particularly among young women, is also recommended.

Acknowledgments. The authors thank the following regional health professionals for their contributions to this study: Adelaide Setubal, Alvaro Koenig, Ana Cristina Alcantara, Ana Katherine Gonçalves, Ana Paula Guimarães, Ernesto Figueiró Filho, Helaine Milanez, Ivete Cristina Canti, Jorge Oliveira Vaz, Juan José Rivas, Kenia Zimmerer Vieira, Marcelino Santos Neto, Marcus Takimura, Maria Alix Leite Araújo, Patricia Leite Rodrigues, Renylena Schmidt, Silvana Maria Quintana, Terezinha Tenório da Silva, Valéria Aparecida da Silva, Weslane Almeida Magalhaes.

Funding. This study was funded by the Brazilian Ministry of Health (MCT/ CNPq/MS-SCTIE-DECIT / CT-Saúde grant no. 550580/2007-7) and the United Nations Office on Drugs and Crime (UNODC) (Termo de Cooperação no. 133/08).

tal outcome. Semin Fetal Neonatal Med. 2004;9(6):429-35.

4. Beck S, Wojdyla D, Say L, Pilar Betran A, Merialdi M, Harris Requejo J, et al. The world- 
wide incidence of preterm birth: a systematic review of maternal mortality and morbidity. Bull World Health Organ. 2010;88(1):31-8.

5. Goldenberg RL, Culhane JF, Iams JD, Romero R. Epidemiology and causes of preterm birth. Lancet. 2008;371(9606):75-84.

6. Savitz DA, Kaufman JS, Dole N, Siega-Riz AM, Thorp JM Jr, Kaczor DT. Poverty, education, race and pregnancy outcome. Ethn Dis. 2004;14(3):322-9.

7. Moreau C, Kaminski M, Ancel PY, Bouyer J, Escande B, Thiriez G, et al. Previous induced abortions and the risk of very preterm delivery: results of the EPIPAGE study. BJOG. 2005;112(4):430-7.

8. da Silva AA, Simões VM, Barbieri MA, Bettiol H, Lamy-Filho F, Coimbra LC, et al. Young maternal age and preterm birth. Paediatr Perinat Epidemiol. 2003;17(4):332-9.

9. Krymko H, Bashiri A, Smolin A, Sheiner E, Bar-David J, Shoham-Vardi I, et al. Risk factors for recurrent preterm delivery. Eur J Obstet Gynecol Reprod Biol. 2004;113(2):160-3.

10. Pollack H, Lantz PM, Frohna JG. Maternal smoking and adverse birth outcomes among singletons and twins. Am J Public Health. 2000;90(3):395-400.

11. Polakowski LL, Akinbami LJ, Mendola P. Prenatal smoking cessation and the risk of delivering preterm and small-for-gestationalage newborns. Obstet Gynecol. 2009; 85.

12. El-Kady D, Gilbert WM, Anderson J, Danielsen B, Towner D, Smith LH. Trauma during pregnancy: an analysis of maternal and fetal outcomes in a large population. Am J Obstet Gynecol. 2004;190(6):1661-8.

13. Newman RB, Goldenberg RL, Iams JD, Meis PJ, Mercer BM, Moawad AH, et al. Preterm prediction study: comparison of the cervical score and Bishop score for prediction of spon- taneous preterm delivery. Obstet Gynecol. 2008;112(3):508-15.

14. Ministério da Saúde, Departamento de Informática do Sistema Único de Saúde (BR). Informações de saúde: nascidos vivos. Notas técnicas [Internet]. Rio de Janeiro: MS/ DATASUS. Available from: http://tabnet. datasus.gov.br/cgi/sinasc/nvdescr.htm Accessed 20 August 2011.

15. Silveira MF, Santos IS, Barros AJ, Matijasevich A, Barros FC, Victora CG. Increase in preterm births in Brazil: review of population-based studies. Rev Saude Publica. 2008;42(5):957-64

16. Passini R Jr, Tedesco RP, Marba ST, Cecatti JG, Guinsburg R, Martinez FE, et al. Brazilian multicenter study on prevalence of preterm birth and associated factors. BMC Pregnancy Childbirth. 2010;19;10:22.

17. Aragão VM, da Silva AA, de Aragão LF, Barbieri MA, Bettiol H, Coimbra LC, et al. Risk factors for preterm births in São Luíz, Maranhão, Brazil. Cad Saude Publica. 2004; 20(1):57-63.

18. Silva AM, de Almeida MF, Matsuo T, Soares DA. Fatores de risco para nascimentos prétermo em Londrina, Paraná, Brasil. Cad Saude Publica. 2009;25(10):2125-38.

19. Ruiz-Pérez I, Plazaola-Castaño J, Del RíoLozano M. Physical health consequences of intimate partner violence in Spanish women. Eur J Public Health. 2007;17(5):437-43.

20. Audi CA, Segall-Corrêa AM, Santiago SM, Andrade Mda G, Pèrez-Escamila R. Violence against pregnant women: prevalence and associated factors. Rev Saude Publica. 2008; 42(5):877-85.

21. Centers for Disease Control and Prevention (US). Adverse health conditions and health risk behaviors associated with intimate partner violence-United States, 2005. MMWR Morb Mortal Wkly Rep. 2008;57(5):113-7.
22. Zhang L, González-Chica DA, Cesar JA, Mendoza-Sassi RA, Beskow B, Larentis N, Blosfeld T. Tabagismo materno durante a gestação e medidas antropométricas do recém-nascido: um estudo de base populacional no extremo sul do Brasil. Cad Saude Publica. 2011;27(9):1768-76.

23. Barros AJ, Cascaes AM, Wehrmeister FC, Martínez-Mesa J, Menezes AM. Tabagismo no Brasil: desigualdades regionais e prevalência segundo características ocupacionais. Cien Saude Colet. 2011;16(9):3707-16.

24. Menezes AM, Dumith SC, Martínez-Mesa J, Silva AE, Cascaes AM, Domínguez GG, et al. Mental health problems and smoking among adolescents from Southern Brazil. Rev Saude Publica. 2011;45(4):700-5.

25. Moreno RS, Ventura RN, Brêtas Jr. O uso de álcool e tabaco por adolescentes do município de Embu, São Paulo, Brasil. Rev Esc Enferm USP. 2010;44(4):969-77.

26. Victora CG, Aquino EM, do Carmo Leal M, Monteiro CA, Barros FC, Szwarcwald CL. Maternal and child health in Brazil: progress and challenges. Lancet. 2011;28;377(9780): 1863-76.

27. Gravett MG, Rubens CE, Nunes TM; GAPPS Review Group. Global report on preterm birth and stillbirth (2 of 7): discovery science. BMC Pregnancy Childbirth. 2010;10 Suppl 1:S2.

28. Lawn JE, Gravett MG, Nunes TM, Rubens CE, Stanton C; GAPPS Review Group. Global report on preterm birth and stillbirth (1 of 7): definitions, description of the burden and opportunities to improve data. BMC Pregnancy Childbirth. 2010;10 Suppl 1:S1.

Manuscript received on 22 December 2011. Revised version accepted for publication on 30 July 2012.
RESUMEN

\section{Prevalencia y factores correlativos del parto prematuro en las jóvenes parturientas que acuden a los hospitales públicos del Brasil}

Objetivo. Determinar la prevalencia y los factores de riesgo de parto prematuro (menos de 37 semanas de gestación) en las jóvenes embarazadas del Brasil.

Métodos. Se llevó a cabo un estudio transversal a escala nacional en jóvenes parturientas de 15 a 24 años de edad que acudieron a las maternidades públicas brasileñas en el 2009. Los entrevistadores administraron cuestionarios al ingresar la parturienta en la maternidad (o poco después de parto, si las mujeres participantes tenían demasiado dolor como para responder durante el trabajo del parto). Las participantes respondieron a un cuestionario que recopilaba datos demográficos, conductuales y clínicos.

Resultados. Se incluyeron en el estudio un total de 2071 (86,3\%) parturientas de las 2400 invitadas a participar. La media de edad fue de 20,2 años (desviación estándar [SD]: 2,7) y el promedio de años de enseñanza escolar fue de 8 (SD: 2,4). Se produjo un parto prematuro en 450 mujeres $(21,7 \%)$. La proporción más alta de parto prematuro $(36,1 \%)$ se observó en la región del Norte y la proporción más baja $(6,9 \%)$ en la región del Sur. En el modelo final de regresión logística con variables múltiples, el vivir en la región del Norte (razón de posibilidades [OR]: 1,43; intervalo de confianza [IC] de 95\%: 1,28-1,59); el tener ingresos mensuales inferiores a dos veces el salario mínimo brasileño (OR: 1,27, IC de 95\%: 1,01-1,60); el haber sido víctima de violencia doméstica (OR: 2,27, IC de 95\%: 1,23-4,18); y el haber recibido una atención prenatal inadecuada (OR: 3,17, IC de 95\%: 2,54-3,97) seguían siendo factores correlativos significativos de parto prematuro en esta población.

Conclusiones. Los resultados muestran una alta prevalencia del parto prematuro en las mujeres jóvenes del Brasil. El parto prematuro presenta una etiología multifactorial. Se deben destinar más recursos de salud pública para acelerar el conocimiento de este complejo proceso.

Palabras clave
Trabajo de parto prematuro; embarazo en adolescencia; atención prenatal; Brasil. 